\title{
PERALIHAN KEKUASAAN PRESIDEN DALAM LINTASAN SEJARAH KETATANEGARAAN INDONESIA
}

\author{
Hayatun Na'imah
}

\begin{abstract}
The process of the power transition from President Soekarno to President Soebarto left the story of political issues. One of the important issues marked the downfall of Sukarno as president is Nawaksara incident. The transition from President Subarto to President BJ Habibie started with students' strikes that forced Subarto to step down from his position as President. The strike was ended with resignation of Soeharto. Therefore, the vice president, Habibie, was appointed to be President. This raised a polemic about the legiticay of Habibie as President. The next power transition is from President Habibie to Abdurrahman Wabid and from President Abdurrahman Wahid to Megawati Sukarnoputri. The transition from President Abdurrahman Wabid to Megawati Sukarnoputri started with the emergence of many participantpolitical parties in the election. It made more than one candidate for President so the election of President was done by MPR. That period is considered as the most democratic power transition process in the history of the Indonesian state administration. Susilo Bambang Yudoyono, who was the president after megawati, was the first president elected by people through direct election.
\end{abstract}

\begin{abstract}
Abstrak:Proses peralihan kekuasaan Presiden Soekarno ke Presiden Soeharto telah meninggalkean cerita yang sarat dengan muatan politik dan peristiwa Nawaksara sebagai suatu hal yang dianggap penting yang menandai tergulingnya Soekarno sebagai Presiden. Peralihan kekuasaan Presiden Soeharto ke Presiden B.J. Habibie yang diawali dengan demonstrasi dari mahasiswa yang menuntut Soeharto untuk. mundur dari jabatannya sebagai Presiden. Yang berakbir dengan pendunduran diri dari Soeharto, yang kemudian jabatan sebagai Presiden diserahkan kepada Wakilnya B.J. Habibie, yang menimbulkan polemik tentang keabsahan Habibie sebagai Presiden. Peralihan kekuasaan dari Presiden Habibie ke Presiden Abdurrahman Wahid, dari Abdurrahman Wabid ke Presiden Megawati Soekarno Putriyang dimulai dengan banyaknya partai politik peserta Pemilu yang akbirnya menimbulkan lebih dari satu orang calon Presiden, sehingga dilakukan pemilihan Presiden oleh MPR. Pada masa ini dianggap proses peralihan kekuasaan Presiden yang paling demokratis dalam sejarah ketatanegaraan Indonesia, yang mana pada Presiden sebelumnya dilaksanakan dengan pengangkatan karena selalu dengan calon tunggal. Pada peralihan kekuasaan Presiden dari Megawati Soekarno Putri ke Presiden Susilo Bambang Yudiyono untuk pertama kalinya Presiden lansung dipilih oleh rakyat
\end{abstract}

\section{Kata kunci ; Peralihan Kekuasaan, Presiden}




\section{Pendahuluan}

Berbicara mengenai sejarah peralihan kekuasaan Presiden, berarti kita melihat kepada aspek sejarah keberadaan pimpinan nasional yaitu Presiden yang pernah ada dan terjadi di negara Republik Indonesia. Sejak tahun 1945 sampai dengan tahun 1966 (dari masa Presiden Soekarno ke Presiden Soeharto), tahun 1966 sampai dengan tahun 1998 (dari masa Presiden Soeharto ke Presiden B.J. Habibie) tahun 1998 sampai dengan tahun 1999 (dari masa Presiden B.J. Habibie ke Presiden Abdurrahman Wahid) tahun 1999 sampai dengan tahun 2002 (dari masa Presiden Abdurrahman Wahid ke Presiden Megawati Soekarno Putri) dan tahun2002 sampai dengan tahun 2004 (dari masa Presiden Megawati Soekarno Putri sampai dengan Presiden Susilo Bambang Yudoyono.

\section{Peralihan Kekuasaan Presiden Soekarno ke Presiden Soeharto}

Sehari setelah Proklamasi Kemerdekaan Republik Indonesia pada tanggal 17 Agustus 1945, Panitia Persiapan Kemerdekaan Indonesia (PPKI) bersidang di Jakarta untuk mengesahkan Undang-Undang Dasar Negera Republik Indonesia serta memilih Presiden dan Wakil Presiden. Dalam persidangan yang berlangsung relatif singkat sebuah naskah yang terkenal dengan sebutan UUD 1945 disahkan menjadi Undang-Undang Dasar Negara Republik Indonesia. Soekarno dan Warga Negara Indonesia (semua anggota berdiri dengan menyanyikan lagu Indonesia Raya, sesudahnya diserukan dengan hidup Bung Hatta 3X).

Sejak itulah Republik Indonesia mempunyai Presiden yang memimpin kekuasaan eksekutif tertinggi yang menjalankan roda pemerintahan.

Pada masa Republik Indonesia, pengaturan masa jabatan Presiden dijumpai dalam Pasal 7 UUD 1945 yang berbunyi:

Presiden Republik Indonesia memegang masa jabatan Presiden selama lima tahun dan sesudahnya dapat dipilih kembali".

Setelah PPKI memilih Ir. Soekarno sebagai Presiden Republik Indonesia yang pertama pada tanggal 18 Agustus 1945, Presiden Soekarno terus memangku Jabatan Presiden sampai terbentuknya Negara Federal Republik Indonesia Serikat (27 Desember 1949). Antisipasi pembuatan UUD 1945 (Aturan Tambahan) bahwa:

1) Dalam enam bulan sesudah akhirnya peperangan Asia Timur Raya, Presiden Indonesia mengatur dan menyelenggarakan segala hal yang ditetapkan dalam Undang-Undang Dasar ini.

2) Dalam enam bulan sesudah Majelis Permusyawaratan Rakyat dibentuk. Majelis itu bersidang untuk menetapkan Undang-Undang Dasar.

Ternyata merupakan wishful thingking. Situasi politik setelah Proklamasi Kemerdekaan tidak mungkin dilangsungkan pemilihan umum (masa revolusi fisik). 
Pada masa Republik kedua. Dengan berlakunya Konstitusi RIS 1949 penyelenggaraan pemilihan Presiden pada masa ini berdasarkan Pasal 69 ayat (12) Konstitusi RIS yang berbunyi " Presiden dipilih oleh orang-orang yang Mohammad Hatta pada saat itu juga dipilih secara aklamasi sebagai Presiden dan Wakil Presiden Republik Indonesia. ${ }^{1}$

Adapun pelaksanaan pemilihan Presiden pada rapat PPKI tersebut dapat diketahui dari notulen rapat berikut di bawah ini, ${ }^{2}$

\section{SOEKARNO KAITYO:}

Sidang saya buka lagi. Menurut acara Tuan sekalian maka kita akan membicarakan peraturan peralihan, tetapi oleh karena pers menunggu saya hal yaitu siapa yang dipilih menjadi Presiden dan Wakil Presiden Negara Indonesia, maka lebih dahulu daripada aturan peralihan akan saya bicarakan Pasal 3.

Sekarang untuk memenuhi pemerintahan pers, lebih dahulu saya hendak masuk ke dalam acara pemilihan Kepala Negara dan Wakilnya, tetapi lebih dahulu saya minta disyahkan Pasal III dalam Aturan Peralihan, yang Tuan-Tuan sekalian memegangnya untuk pertama kali Presiden dan Wakil Presiden dipilih oleh Panitia Persiapan Kemerdekaan Indonesia, yaitu kita ini.

Bagaimana Tuan-Tuan sekalian, setuju? Kalau setuju maka setuju maka sekarang saya Saya minta Zimokyoka membagikan stembiljet.

\section{OTTO ISKANDAR DINATA IIN (anggota):}

Berhubungan dengan keadaan tempo saya harap supaya pemilihan Presiden ini diselenggarakan dengan aklamasi dan saya memajukan sebagai calon, yaitu Bung Karno sendiri.

\section{SOEKARNO KAITYO (Ketua):}

Tuan-tuan banyak terima kasih atas kepercayaan Tuan, dengan ini saya dipilih oleh Tuan-Tuan sekalian dengan suara bulat menjadi Presiden Republik Indonesia. (Semua anggota berdiri dengan menyanyi lagu Indonesia Raya, diserukan hidup Bung Karno 3X).

\section{OTTO ISKANDAR DINATA INN:}

Pun buat Wakil Kepala Negara Republik Indonesia saya usulkan cara yang baru ini dijalankan. Dan saya usulkan Bung Hatta, menjadi Wakil Kepala dikuasakan oleh pemerintah daerah-daerah bagian tersebut dalam Pasal 2. Dalam memilih Presiden orang-orang yang dikuasakan mencapai kata sepakat".

Dari ketentuan tersebut dapat diketahui bahwa sistem yang berlaku adalah sistem pemilihan yang tidak dilakukan oleh rakyat, baik secara langsung maupun

1 Yusril Ihza Mahendra, Dinamika Tatanegara Indonesia, Gema Insani Press, Jakarta, 1996, hlm. 62

2 Muhammad Yamin, Naskah..., Op Cit, hlm. 425-426 
tidak langsung. Pemilihan dilakukan oleh sebuah badan yang terdiri atas orangorang yang mendapat mandat dari pemerintah daerah-daerah bagian. Badan ini bersifat ad hoc yang berarti tugasnya hanya memilih Presiden. Setelah Presiden terpilih badan itupun bubar. ${ }^{3}$

Menurut Mukhyar Yara ${ }^{4}$

Pemilihan Presiden tersebut dilaksanakan pada tanggal 16 Desember 1949, peristiwa pemilihan Presiden RI ini jika ditinjau dari segi waktu penyelenggaraannya, terlihat agak ganjil, karena disatu pihak pelaksanaannya didasarkan pada ketentuan Pasal 69 ayat (2) UUD RIS 1949, tetapi di lain pihak UUD RIS 1949 itu sendiri belum secara formal berlaku. Namun karena rancangan UUD RIS 1949 (yang dipersiapkan selama Konfrensi Meja Bundar oleh delegasi Republik Indonesia dan Delegasi Negara-negara di Indonesia buatan Belanda yang disebut, Bijeenkonst voor federal overlag/pertemuan untuk Permusyawaratan Federal), telah diterima/disetujui oleh Dewan Perwakilan Rakyat Republik Indonesia (KNIP) dan Dewan Perwakilan Rakyat daerahdaerah bagian RIS lainnya pada tanggal 14 Desember 1949, maka secara materiil penyelenggaraan pemilihan Presiden RIS adalah tetap sah secara konstitusional.

Pada UUD ini tidak mengatur mengenai masa jabatan Presiden dan menyerahkan kepada Konstituante yang baru akan dibentuk.

Pemilihan Presiden pada periode ini, juga dilakukan secara aklamasi dan Ir. Soekarno terpilih kembali untuk kedua kalinya. Jadi, Presiden dengan calon tunggal terulang kembali. ${ }^{5}$ Soekarno yang memangku jabatan Presiden RIS mulai tanggal 27 Desember 1949, terus memangku jabatannya sampai berakhirnya masa federasi pada tanggal 17 Agustus 1950.

Pada masa Republik ketiga. Periode masa berlakunya UUDS 1950 ini berlangsung pada tanggal 17 Agustus 1950 sampai dengan 5 Juli 1959, yaitu ketika UUD 1945 dinyatakan berlaku kembali ke seluruh wilayah negara Republik Indonesia melalui Dekrit Presiden 5 Juli 1959.

Pemilihan Presiden pada periode ini berlandaskan pada Pasal 45 ayat (3) UUDS 1950 yang berbunyi: “Presiden dan Wakil Presiden dipilih menurut aturan yang ditetapkan dengan Undang-Undang".

Namun sampai berakhirnya periode ini, undang-undang yang dimaksud tidak terbentuk. Demikian pula konstituante hasil pemilihan umum 1955, tidak berhasil membentuk undang-undang Dasar baru yang diharapkan dapat mengatur masalah pemilihan Presiden. Badan tersebut dibubarkan oleh Presiden Soekarno sebelum tugasnya selesai. ${ }^{6}$

3 Harun Alrasyid, Pengisian..., Op Cit, hlm. 30

4 Mukhyar Yara, Pengisian..., Op Cit, hlm. 177

5 Harun Alrasyid, Pengisian..., Loc Cit, hlm. 29

6 Harun Alrasyid, Loc Cit. 
Maka berdasarkan ketentuan peralihan yang tercantum dalam Pasal 141 ayat (3) UUDS 1950, yang berbunyi:

Alat-alat perlengkapan berkuasa yang sudah ada dan peraturan-peraturan serta keputusan-keputusan yang berlaku pada suatu perubahan dalam UndangUndang Dasar mulai berlaku, dilanjutkan sampai diganti yang lain menurut Undang-Undang Dasar, kecuali jika melanjutkannya itu berlawanan dengan ketentuan-ketentuan baru dalam Undang-Undang Dasar yang tidak memerlukan peraturan undang-undang atau tindakan pelaksanaan selanjutnya.

Pemangku jabatan Presiden di masa berlakunya UUDS 1950, adalah Ir. Soekarno yang tetap akan memangku jabatan Presiden di bawah UUDS 1950. pembuat UUD 1950 tidak mengatur masa jabatan Presiden. Soekarno yang berdasarkan ketentuan peralihan terus memegang jabatan Presiden, tidak perlu melepaskan masa jabatannya sampai konstituante membentuk UUD yang tetap dan dilakukan pemilihan Presiden (baru). Konstituante itu memang berhasil dibentuk, tetapi dibubarkan sebelum selesai melaksanakan tugasnya. ${ }^{7}$

Pada masa Republik keempat, yang kembali berdasarkan UUD 1945, Presiden Soekarno tetap memangku jabatan berdasarkan Pasal II Aturan Peralihan yang berbunyi: "Segala badan negara dan peraturan yang ada masih berlaku, selama belum diadakan yang baru menurut Undang-Undang Dasar ini” sampai terpilihnya Presiden (baru) oleh Majelis Permusyawaratan Rakyat hasil pemilihan umum. ${ }^{8}$

Sejak kembali ke UUD 1945, melalui Dekrit Presiden 5 Juli 1959, maka secara otomatis ketentuan tentang peralihan kekuasaan Presiden dilaksanakan sesuai ketentuan UUD 1945. sedangkan jabatan Presiden yang ada sebelumnya adalah hasil pemilihan Presiden yang diselenggarakan berdasarkan ketentuan UUDS 1950.

Menurut Pasal 6 ayat (2) UUD 1945, Presiden dan Wakil Presiden dipilih oleh Majelis Permusyawaratan Rakyat. Tetapi, ketika UUD 1945 dinyatakan berlaku kembali MPR belum terbentuk (dan lembaga negara inipun tidak dikenal dalam UUDS 1950), sehingga Pasal 6 ayat (2) tersebut tidak bisa diterapkan untuk penyelenggaraan pemilihan Presiden dan Wakil Presiden. Di lain pihak ketentuan Pasal III Aturan Peralihan UUD 1945 juga tidak bisa dipergunakan untuk keperluan yang dimaksud, karena:

1) Pasal ini hanya berlaku untuk pemilihan Presiden dan Wakil Presiden yang pertama kali, dimana penyelenggaraannya telah dilaksanakan pada tanggal 18 Agustus 1945, dan

7 Harun Alrasyid, Masalah Pengisian Jabatan Presiden, Sejak Sidang Persiapan Kemerdekaan Indonesia sampai Sidang Majelis Permusyawaratan Rakyat 1993, (disertasi), Universitas Indonesia, Jakarta, 1993, hlm. 74

8 Ibid, hlm. 75 
2) Lembaga Negara yang berwenang melaksanakan pemilihan Presiden dan Wakil Presiden menurut Pasal III Aturan Peralihan UUD 1945, yaitu PPKI, sudah tidak ada lagi ketika UUD 1945 dinyatakan berlaku kembali pada tanggal 5 Juli 1959.?

Untuk menghindari kekosongan jabatan Presiden, maka berlakulah kembali ketentuan Pasal II Aturan Peralihan UUD 1945, yang berbunyi: "Segala badan negara dan peraturan yang ada masih langsung berlaku, selama belum diadakan yang baru menurut Undang-Undang Dasar ini'. ${ }^{10}$

Selanjutnya, untuk melaksanakan ketentuan-ketentuan UUD 1945 sebagai tindak lanjut dikeluarkannya Dekrit Presiden 5 Juli 1959, maka melalui Penetapan Presiden Republik Indonesia No. 2 Tahun 1959 (LN. 1959) dibentuklah Majelis Permusyawaratan Rakyat Sementara (MPRS). Pembentukan MPRS tersebut melanggar aturan yang terdapat dalam Pasal IV Aturan Peralihan UUD 1945, yang berbunyi: "Sebelum Majelis Permusyawaratan Rakyat, Dewan Perwakilan Rakyat dan Dewan Pertimbangan Agung dibentuk menurut Undang-Undang Dasar ini, segala kekuasaan dijalankan oleh Presiden dengan ketentuan sebuah Komite Nasional". Jadi pembentukan MPR tersebut bukan menggunakan Penetapan Presiden tetapi melalui undang-undang.

Sejak negara kembali kepada UUD 1945 tersebut, berarti ketentuanketentuan yang ada dalam undang-undang Dasar tersebut tentunya harus diberlakukan juga. Tetapi pada kenyataannya dalam praktik kehidupan kenegaraan masih terjadi penyimpangan-penyimpangan terhadap UUD 1945. Salah satu penyimpangan tersebut adalah dikeluarkannya TAP MPRS No. III/ MPRS/1963 tentang pengangkatan Pimpinan Besar Revolusi Bung Karno menjadi Presiden Republik Indonesia seumur hidup.

Dengan TAP MPRS No. III/MPRS/1963 tersebut, menggambarkan pada satu itu tidak akan terjadi peralihan kekuasaan (pergantian) Presiden sebagaimana yang diatur oleh UUD 1945, tidak ubahnya situasi itu sebagaimana layaknya sebuah negara kerajaan yang dipimpin oleh seorang raja yang berkuasa seumur hidupnya.

Namun demikian perjalanan sejarah bangsa Indonesia selanjutnya menentukan lain tentang peralihan kekuasaan Presiden tersebut. Hal ini dimulai dengan terjadinya Gerakan 30 September 1965 (G-30-S/PKI) yang dilakukan oleh Partai Komunis Indonesia (PKI), yang gerakannya secara fisik/militer dipimpin oleh Letnan Kolonel Untung Sutopo, Komandan Batalyon I resiemn Cakrabirawa (Pasukan Pengawal Presiden). Pada tanggal 1 Oktober 1965 dinihari bergerak menculik dan membantai para Perwira Tinggi Angkatan Darat di Lubang Buaya yang tujuannya mengadakan $c u p$, terhadap pemerintah yang sah pada waktu itu, tetapi kemudian $c$ p tersebut tidak berhasil.

9 Mukhyar Yara, Pengisian..., Op Cit, hlm. 193

${ }^{10}$ Harun Alrasyid, Pengisian..., Op Cit, hlm. 45 
Akibat adanya pemberontakan tersebut, maka negara dan bangsa Indonesia dalam keadaan yang tidak menentu dan penuh saling curiga. Pada tanggal 2 Oktober 1965 setelah keadaan Ibukota Jakarta dapat dikuasai oleh Pasukan RPKAD, maka Mayor Jendral Soeharto menemui Presiden Soekarno di Istana Negara Bogor. Dalam pertemuan tersebut Presiden memutuskan untuk secara langsung memegang tampuk Pimpinan Angkatan Darat, yang semenjak tanggal 1 Oktober 1965 untuk sementara Pimpinan Angkatan Darat dipegang oleh Mayor Jendral Soeharto. Sebagai pelaksana harian, Presiden menunjuk Mayor Jendral Pranoto Rekso Samudro. Untuk menyelenggarakan pemulihan keamanan dan ketertiban seperti sedia kala ditunjuk Mayor Jendral Soeharto, sebagai Panglima Komando Strategi Angkatan Darat (Kostrad). ${ }^{11}$ Dari sinilah kemudian Mayor Jendral Soeharto mengadakan pembersihan atau operasi baik fisik, militer dan mental dalam rangka menegakkan kembali kewibawaan pemerintahan yang telah dicoreng oleh PKI tersebut.

Peranan Mayor Jendral Soeharto dalam memulihkan keamanan negara semakin dikenal oleh seluruh rakyat Indonesia dan pada tanggal 6 Oktober 1965 dalam Sidang Paripurna Kabinet Dwikora di Bogor ditetapkan Kebijaksanaan Presiden Soekarno mengenai Penyelesaian G-30 S/PKI. Dalam penyelesaian ini Presiden menggariskan kebijaksanaan sebagai berikut:

"Babwa aspek-aspek Gerakan 30 September akan diselesaikan sendiri oleh Presiden; aspek militer administratif diserabkan penyelesaiannya kepada Mayor Jendral Pranoto Pelaksanaan Tugas sehari-hari Men/Pangad, sedangkan penyelesaian aspek militer teknis masalah keamanan dan ketertiban diserahkan kepada Mayor Jendral Soebarto". ${ }^{12}$

Keberadaan Mayor Jendral Soeharto kemudian semakin kokoh, karena pada tanggal 16 Oktober 1965 Soeharto dilantik oleh Presiden Soeharto sebagai Menteri/Pangad (Panglima Angkatan Darat). Sejak itulah pemberantasan terhadap sisa-sisa G-30 S/PKI dan ormas-ormasnya serta perbersihan sipil/ militer dari unsur-unsur G-30 S/PKI.

Keadaan ekonomi pun menjadi semakin sulit, muncul gerakan-gerakan rakyat untuk penyelesaian yang seadil-adilnya terhadap Gerakan 30 September PKI. Berbagai aksi terbentuk, seperti Kesatuan Aksi Mahasiswa Indonesia (KAMI), Kesatuan Aksi Pemuda Pelajar Indonesia (KAPPI), Kesatuan Aksi Buruh Indonesia (KABI) dan lain-lain.

Dalam menghadapi kesulitan perekonomian kemudian Pemerintah pada tanggal 13 Desember 1965 melakukan devaluasi uang rupiah, akibatnya nilai rupiah merosot tajam dan harga kebutuhan pokok melonjak naik di pasaran. Melihat kondisi seperti ini, dalam keadaan serba tidak puas dan tidak sabar, akhirnya tercetuslah Tri Tuntutan Rakyat, yang disingkat dengan TRITURA. Dengan dipelopori oleh KAMI dan KAPPI, pada tanggal 10 Januari 1966

\footnotetext{
${ }^{11}$ Sekretariat Negara, Tiga Pulub Tabun ind Merdeka, cet. Ke III, Tiara Pustaka, Jakarta, 1980, hlm. 51

12 Ibid, hlm. 60
} 
kesatuan-kesatuan aksi yang memenuhi front Pancasila memenuhi halaman DPR-GR dan mengajukan tiga buah tuntutan yang dikenal dengan TRITURA tersebut yang isinya adalah:

1. Pembubaran PKI

2. Pembersihan Kabinet dari Unsur-unsur G-30 S/PKI, dan

3. Penurunan harga/perbaikan ekonomi. ${ }^{13}$

Dari adanya TRITURA tersebut keadaan pemerintahan semakin goyang dan kemudian pada tanggal 24 Februari 1966 Presiden Soekarno mengadakan perubahan terhadap Kabinet Dwikora, yaitu yang diberi nama dengan kabinet 100 Menteri. Ternyata hal tersebut malah semakin menimbulkan kemarahan rakyat karena Kabinet tersebut di dalamnya terdapat tokoh-tokoh yang dicurigai karena keterlibatannya dalam Gerakan 30 September PKI.

Menyadari keadaan negara yang semakin sulit, menghadapi gejolak dari masyarakat dan kondisi Presiden Soekarno yang semakin melemah kesehatannya diadakanlah tindakan yang penting untuk mengatasi hal tersebut. Tindakan tersebut adalah suatu tindakan yang penting dalam sejarah ketatanegaraan Indonesia, yaitu dikeluarkannya oleh Presiden suatu "Surat Perintah" kepada Letnan Jendral Soeharto Menteri Panglima Angkatan Darat, pada tanggal 11 Maret 1966. Surat perintah ini kemudian dikenal dengan nama "Surat Perintah 11 Maret (SUPERSEMAR). ${ }^{14}$

Berlandaskan kepada SUPERSEMAR tersebut, pengembannya, Letnan Jendral Soeharto, telah mengambil langkah-langkah yang penting dan memberi arah baru kepada perjalanan hidup bangsa dan negara.

SUPERSEMAR ini dapat dikatakan sebagai permulaan dari peralihan kekuasaan Presiden yang pertama dalam sejarah ketatanegaraan Republik Indonesia. Hal ini dapat dikatakan demikian karena Surat Perintah Sebelas Maret tersebut berisi

"Memerintahkan kepada Letnan Jendral Soeharto sebagai Menteri Panglima Angkatan Darat untuk dan atas nama Presiden/Panglima Tertinggi/ Pimpinan Besar Revolusi" untuk mengambil beberapa tindakan sebagai berikut:

1) Mengambil segala tindakan yang dianggap perlu, untuk terjaminnya keamanan dan ketenangan serta kestabilan pemerintahan dan jalannya revolusi serta menjamin keselamatan pribadi dan kewibawaan Pimpinan Presiden/Mandataris MPRS demi untuk keutuhan bangsa dan Negara Republik Indonesia, dan melaksanakan dengan pasti segala ajaran Pimpinan Republik Indonesia, dan melaksanakan dengan pasti segala ajaran Pimpinan Besar Revolusi.

${ }^{13}$ Ibid, hlm. 79

${ }^{14}$ Joeniarto, Sejarah Ketatanegaraan Republik Indonesia, Bumi Aksara, Jakarta, 1990, hlm. 137 
2) Mengadakan koordinasi pelaksanaan perintah dengan panglima-panglima Angkatan lain dengan sebaik-baiknya.

3) Supaya melaporkan segala sesuatu yang bersangkut paut dalam tugas dan tanggung jawabnya seperti tersebut di atas.

Menurut Suwoto Mulyosudarmo, ${ }^{15}$

"Dengan dikeluarkannya Surat Perintah 11 Maret 1966, tidak berarti telah terjadi peralihan kekuasaan kepada Letnan Jendral Soeharto. Presiden Soekarno belum melepaskan tanggung jawab selaku pemegang kekuasaan pemerintahan. Secara hukum Presiden Soekarno masih memegang kekuasaan pemerintahan. Karena itu, sesuai dengan Surat Perintah Sebelas Maret 1966 pelaksanaannya, peristiwa itu dapat dikualifikasikan sebagai pelimpahan kuasa (mandaatverlening) sebagian kekuasaan pemerintahan. Beberapa petunjuk yang menyatakan Supersemar ini merupakan surat kuasa adalah: (a. Letnan Jendral Soeharto bertindak "atas Presiden Panglima Tertinggi/Pimpinan Besar Revolusi", (b) Letnan Jendral Soeharto tidak bertanggungjawab kepada MPRS. Dengan adanya pelimpahan kuasa, pertanggungjawaban terhadap MPRS tetap berada pada pemberi kuasa (Presiden Soekarno)".

Hal ini dapat dijelaskan bahwa, berdasarkan Surat Perintah Sebelas Maret Letnan Jendral Soeharto bertindak atas nama Presiden. Tindakan yang dilakukan atas nama Presiden secara formal tetap merupakan tanggung jawab Presiden. Dengan demikian pembubaran PKI dan pembersihan Kabinet dari unsurunsur PKI dilakukan atas nama dan atas tanggung jawab Presiden Soekarno. Dengan demikian, urutan pertanggungjawaban adalah sebagai berikut: Letnan Jendral Soeharto selaku pemegang Surat Perintah Sebelas Maret 1966 mempertanggungjawabkan tugasnya kepada Presiden Soekarno, dan Presiden Soekarno mempertanggungjawabkannya kepada MPRS. Pertanggungjawaban Letnan Jendral Soeharto kepada Presiden merupakan pertanggungjawaban internal, sedangkan pertanggungjawaban Presiden Soekarno kepada MPRS oleh Suwoto disebut sebagai pertanggungjawaban eksternal. Dengan dikeluarkannya Surat Perintah Sebelas Maret 1966, Presiden Soekarno belum melepaskan tanggung jawannya baik selaku Mandataris maupun selaku Kepala Negara. ${ }^{16}$

Berdasarkan Surat Perintah Sebelas Maret tersebut, maka Letnan Jendral Soeharto yang menjabat sebagai Menteri Panglima Angkatan Darat menerima tugas atas nama Presiden dan menjalankan pemerintahan untuk mengambil tindakan mengamankan jalannya pemerintahan negara pada waktu itu.

Penggunaan Surat Pemerintahan Sebelas Maret tersebut selanjutnya dititik beratkan untuk penertiban keadaan kembali dalam rangka menghidupkan fungsifungsi pemerintahan dan kehidupan sosial pada umumnya, untuk menghilangkan segala yang abnormal dan mengembalikan kepada keadaan yang seharusnya.

${ }^{15}$ Ibid, hlm. 141

16 Suwoto Mulyosudarmo, Ibid. 
Dengan dikeluarkan Surat Perintah tersebut di atas dan diambulnya tindakan-tindakan tersebut oleh Pemegang Surat Perintah, ternyata memperoleh sambutan yang baik sekali dari rakyat. Semenjak diumumkannya Surat Perintah tersebut beserta juga tindakan-tindakannya, membanjir secara spontan persyaratan-persyaratan dukungan atas perintah tersebut dari segala golongan dan lapisan masyarakat di pelosok tanah air. ${ }^{17}$

Pada tanggal 20 Juni 1966 MPRS telah mengadakan Sidang Umum ke IV (empat) yang berlangsung selama lima belas hari dan telah menghasilkan 24 (dua puluh empat) ketetapan. Salah satu dari Ketetapan MPRS tersebut adalah, TAP MPRS No. IX/MPRS/1966 tentang Surat Perintah Presiden/Panglima Tertinggi Angkatan Bersenjata Republik Indonesia/Pimpinan Besar Revolusi/ Mandataris MPRS RI, yang berisi mengukuhkan adanya Surat Perintah Sebelas Maret tersebut. Dalam hal ini berarti memberikan landasan yang kuat dalam melakukan kegiatan kenegaraan bagi pemegang Surat Perintah tersebut (Letnan Jendral Soeharto).

Tampilnya Letnan Jendral Soeharto tersebut secara faktual dapat dikatakan menjadi orang kedua yang penting dalam kepemimpinan nasional pada waktu itu di bawah Presiden Soekarno. Hal inipun terlihat pada waktu Surat Perintah Soekarno membubarkan Kabinet Dwikora dan membentuk Kabinet Ampera, dimana dalam Kabinet Ampera tersebut terdiri dari tiga unsur, yaitu:

a) Pimpinan yaitu Presiden

b) Pembantu Pimpinan yang terdiri dari lima orang Menteri Utama yang bersama-sama merupakan Presideum dengan Letnan Jendral Soeharto. Menteri Utama Bidang Pertahanan dan Keamanan sebagai Ketua Presidium.

c) Anggota-anggota Kabinet, yang terdiri dari 24 Menteri yang masingmasing memimpin Departemen di bawah koordinasi Presidium Kabinet melalui Menteri Utama yang membawahi bidang-bidang yang bersangkutan.

Dengan pengangkatan Letnan jendral Soeharto sebagai Ketua Presidium Kabinet tersebut praktis menjadikan Soeharto sebagai orang yang tampil di dalam pemerintahan, seperti dalam memberikan keterangan di dalam Sidang Pleno terbuka DPR GR tanggal 16 Agustus 1966 mengenai kebijaksanaan yang telah ditempuh dan langkah-langkah yang dilaksanakan pemerintah. Dan telah memberikan Pidato Akhir Tahun (31 Desember 1966) sebagai Ketua Presidium Kabinet melalui Corong RRI dan TVRI ke seluruh pelosok tanah air. Di samping itu pamor Presiden Soekarno semakin memudar, lebih-lebih setelah beliau menyampaikan Pidato "Jas Merah" (jangan sekali-kali meninggalkan sejarah), dimana pidato itu mendapat kecaman dari DPR GR.

${ }^{17}$ Joeniarto, Loc Cit 
Berdasarkan keputusan MPRS No. V/MPRS/1966 Presiden diminta agar melengkapi laporan pertanggungjawaban mengenai sebab-sebab terjadinya peristiwa G-30 S/PKI, karena sebelumnya Presiden (Tanggal 22 Juni 1966) menyampaikan amanat yang berjudul "Nawaksara" (sembilan pasal) yang tidak memuaskan MPRS. Maka pada tanggal 10 Januari 1967 dengan surat, Presiden Soekarno menyampaikan pelengkap Nawaksara kepada pimpinan MPRS.

Surat pelengkap Nawaksara tersebut kemudian oleh Pimpinan MPRS dalam musyawarahnya tanggal 21 Januari 1967 dinyatakan Presiden telah alpa dalam memenuhi ketentuan-ketentuan konstitusional. Dan kemudian DPR GR pada tanggal 9 Februari 1967 mengeluarkan revolusi dan memorandum bahwa apa yang dilakukan oleh Presiden Soekarno dapat membahayakan negara, oleh karena itu DPR GR mengusulkan kepada Pimpinan MPRS agar mengadakan Sidang Istimewa MPRS untuk: ${ }^{18}$

a) Memberhentikan Presiden Soekarno dari jabatannya sebagai Presiden/ Mandataris MPRS dan memilih/mengangkat Pejabat Presiden sesuai dengan Pasal 3 Ketetapan MPRS No. XV/MPRS/1966 tentang Pemilihan/Petunjukan Wakil Presiden dan Tata Cara Pengangkatan Presiden.

b) Memerintahkan kepada Badan Kehakiman yang berwenang untuk mengadakan pengusutan, pemeriksaan dan penuntutan secara hukum.

Melihat situasi yang demikian dan kehidupan kenegaraan dihadapkan pada situasi yang semakin memuncak, rupanya Presiden Soekarno menyadarinya. Sehingga pada tanggal 22 Februari 1967 di Istana Merdeka Kekuasaan Pemerintahan diserahkan oleh Presiden Soekarno kepada pengemban Ketetapan MPRS No. XI/MPRS/1966, yaitu Jendral Soeharto, sebagaimana yang tertuang dalam pengumuman Presiden/Mandataris/Panglima Tertinggi ABRI tanggal 10 Februari 1967. Adapun yang menjadi dasar hukum dari penyerahan kekuasaan tersebut adalah TAP MPRS No. XV/MPRS/1966 yang menyebutkan bahwa apabila Presiden berhalangan, maka pemegang Surat Perintah Sebelas Maret memegang jabatan Presiden.

Kemudian secara konstitusional pada tanggal 7 sampai dengan 12 Maret 1967 MPRS mengadakan Sidang Istimewa. Pada Sidang Istimewa inilah dikeluarkan Ketetapan MPRS No. XXXIII/MPRS/1967 yang menetapkan dan memutuskan:

a) Mencabut kekuasaan negara dari Presiden Soekarno dan menarik kembali mandat MPRS dari Presiden Soekarno serta segala kekuasaan pemerintahan negara yang diatur dalam UUD 1945.

${ }^{18}$ Ibid, hlm. 131 
b) Mengangkat pengemban TAP MPRS No.IX/MPRS/1966, Jendral Soeharto sebagai Pejabat Presiden sehingga dipilih Presiden oleh MPR hasil pemilihan umum.

Adapun yang menjadi pertimbangan dari Ketetapan MPRS tersebut adalah:

1) Keseluruhan Pidato Presiden yang berjudul Nawaksara dan pelengkapnya tidak memenuhi harapan rakyat khususnya anggota MPRS, karena tidak memuat secara jelas pertanggungjawaban tentang kebijaksanaan Presiden mengenai pemberontakan G $30 \mathrm{~S} / \mathrm{PKI}$ serta epilognya mengenai kemunduran ekonomi, dan kemerosotan akhlak.

2) Presiden telah menyerahkan kekuasaan pemerintahan kepada pengemban TAP MPRS No. IX/MPRS/1966, Jendral Soeharto.

3) Berdasarkan laporan tertulis Pangkopkamtib/Pengemban TAP MPRS No. IX/MPRS/1966, terdapat petunjuk-petunjuk bahwa Presiden Soekarno telah melakukan kebijaksanaan yang secara tidak langsung menguntungkan G 30 S/PKI.

Dari ketetapan MPRS tersebut di atas, maka berakhirlah secara resmi kekuasaan Presiden Soekarno dan digantikan oleh Soeharto sebagai Pejabat Presiden, yang pada tanggal 12 Maret 1967 disumpah dan dilantik dalam rangkaian Sidang Istimewa MPRS. Inilah peralihan kekuasaan Presiden pertama dalam rangkaian Sidang Istimewa MPRS. Inilah peralihan kekuasaan Presiden pertama dalam sejarah Ketatanegaraan Indonesia. Dan kemudian berdasarkan TAP MPRS No. XLIV/MPRS/1968 tanggal 27 Maret 1968 Jendral Soeharto diangkat sebagai Presiden (penuh). Jendral Soeharto mengakhiri masa peralihannya setelah MPR hasil Pemilu 1971 melakukan pemilihan Presiden pada bulan Maret $1973 .{ }^{19}$

Selanjutnya, pada bulan Maret 1973 MPR hasil Pemilu yang pertama, mengadakan Sidang Umum. Di dalam kesempatan tersebut melalui TAP MPR No. IX/MPR/1973, MPR mengangkat Presiden Soeharto sebagai Presiden untuk kedua kalinya.

Pada waktu tersebut untuk pertama kalinya penyelenggaraan tata cara pemilihan Presiden yang didasarkan pada UUD 1945 mekanismenya diatur melalui Ketetapan MPR, yaitu TAP MPR No. II/MPR/1973, MPR mengangkat Presiden Soeharto sebagai Presiden untuk kedua kalinya.

Pada waktu tersebut untuk pertama kalinya penyelenggaraan tata cara pemilihan Presiden yang didasarkan pada UUD 1945 mekanismenya diatur melalui ketetapan MPR, yaitu TAP MPR No. II/MPR/1973. Di dalam ketetapan tersebut proses pencalonan Presiden dan Wakil Presiden dilakukan secara terpisah. Pemilihan inipun hanya terdapat calon tunggal, yakni Soeharto, sehingga pemilihannya dilakukan secara musyawarah mufakat.

${ }^{19}$ Harun Alrasyid, Masalah Pengisian..., Op Cit, hlm. 76 
Kemudian pada periode berikutnya hasil Pemilu 1977 menyelenggarakan pemilihan Presiden pada tanggal 22 Maret 1978. Pelaksanaan pemilihan tersebut berdasarkan Pasal 6 ayat (2) UUD 1945 dan menggunakan TAP MPR No. II/ MPR/1973 tentang Tata Cara Pemilihan Presiden dan Wakil Presiden. Kemudian terpilih sebagai Presiden adalah Soeharto dengan cara pengangkatan melalui TAP MPR No. X/MPR/1978.

Pada pemilihan-pemilihan Presiden berikutnya pada tahun 1983, 1988, 1993, dan 1998 juga terdapat calon tunggal, yaitu tetap Jendral Soeharto. Harun Alrasyid, berpendapat telah timbul tradisi calon tunggal dalam praktik pemilihan Presiden di Indonesia. Harun Alrasyid mengatakan, karena pada pemilihan Presiden Republik Indonesia pada 18 Agustus 1945 dan pemilihan Presiden Republik Indonesia Serikat pada 16 Desember 1949 juga terdapat calon tunggal, yaitu Soearno, maka dapat ditarik kesimpulan bahwa dalam praktik ketatanegaraan di Indonesia telah timbul "tradisi calon tunggal" dalam soal pemilihan Presiden. ${ }^{20}$

Dengan demikian dapat diartikan bahwa dalam lima kali pemilihan Presiden selama masa peralihan, Majelis Permusyawaratan Rakyat terus menerus memilih Jendral Soeharto, yang merupakan calon tunggal sampai akhir masa jabatannya pada tanggal 21 Mei 1998.

\section{Peralihan Kekuasaan Presiden Soeharto ke Presiden B.J. Habibie}

Keputusan Presiden Soeharto untuk berhenti dari jabatannya sebagai Presiden, bagaimanapun, terasa mengejutkan, walaupun sehari sebelumnya telah diumumkan bahwa Pak Harto akan mengundurkan diri. Tak sedikit yang menerka apa pertimbangan utama Pak Harto untuk memilih sikap itu dan siapa yang mendorongnya untuk mengambil keputusan tersebut. Kejutan kearah mundurnya Soeharto diawali oleh keterangan pers Ketua DPR/MPR Harmoko seusia rapat Paripurna DPR, Senin 18 Mei 1998. ${ }^{21}$

Tuntutan reformasi yang didengungkan mahasiswa dan masyarakat yang tergabung dalam aksi keprihatinan menuntut adanya reformasi di segala bidang, berpuncak pada tuntutan turunnya Presiden Soeharto dari jabatan sebagai Presiden, telah tercapai pada tanggal 21 Mei 1998, dimana Presiden Soeharto bersedia turun dari jabatan Presiden. Tahapan ini merupakan langkah awal dari sekian banyak tuntutan reformasi yang dikumandangkan oleh mahasiswa dan masyarakat, untuk segera keluar dari krisis yang sedang melanda bangsa ini. Mencermati detik-detik yang menegangkan dan menentukan bagi bangsa kita, pada tanggal 21 Mei 1998 jam 09.05 WIB Presiden Soeharti resmi meletakkan Presiden. ${ }^{22}$

${ }^{20}$ Harun Alrasyid, “Tradisi Calon Tunggal dalam Pemilihan Presiden”, Suara Pembaharuan,2 Maret 1993.

${ }^{21}$ Muhammad Najib dan Kuat Sukardiyono, Amin Rais Sang Demokrat, Gema Insani Press, Jakarta, 1998, hlm. 29

${ }^{22}$ Ni'matul Huda, Hukum ..., Op Cit, hlm. 85 
Di dalam ruang Jepara Istana Merdeka, ruangan resmi Presiden menerima tamu-tamu negara, duduklah Pimpinan MPR RI (Harmoko, Syarwan Hamid, Abdul Gafur, Ismail Hasan Metarium, Fatimah Achmad). Sayup-sayup terdengar suara Pak Harmoko. Berdiri di hadapan mikrofon, didampingi Wakil Presiden B.J. Habibie dan Mensesneg Drs. Saadillah Mursyid, disorot kamera TVRI dan TV swasta dalam dan luar negeri serta wartawan media cetak, Presiden mengumumkan kepada seluruh rakyat Indonesia tentang pengunduran dirinya:

"Dengan memperhatikan ketentuan pasal 8 UUD 1945 dan secara sungguh-sungguh memperhatikan pandangan Pimpinan DPR/MPR dan fraksifraksi yang ada di dalamnya saya memutuskan untuk menyatakan berhenti dari jabatan saya sebagai Presiden Republik Indonesia terhitung sejak saya bacakan pernyataan ini, pada hari ini Kamis 21 Mei 1998. pernyataan berhenti dari Presiden RI, saya sampaikan dihadapan saudara-saudara pimpinan DPR RI dan juga MPR pagi ini pada kesempatan silaturrahmi. Sesuai dengan Pasal 8 UUD 1945, maka Wakil Presiden B.J. Habibie yang akan melanjutkan sisa jabatan Presiden Mandataris MPR RI 1998-2003, oleh karena keadaan tidak memungkinkan untuk menyelenggarakan pengucapan sumpah di hadapan DPR maka untuk menghindari kekosongan pimpinan dalam menjalankan Pemerintahan Negara kiranya saudara Wakil Presiden sekarang juga akan melaksanakan sumpah jabatan terhadap Mahkamah Agung Republik Indonesia”.

Berakhirlah sudah suatu kepemimpinan yang berlangsung lebih dari tiga puluh tahun. Padahal baru saja tujuh puluh hari lalu, tepatnya pada tanggal 11 Maret 1998 Presiden Soeharto mengangkat sumpah di hadapan Sidang Paripurna MPR sebagai Presiden/Mandataris MPR masa bakti 1998-2003. ${ }^{23}$

Setelah selesainya pernyataan tersebut dibacakan, pada saat itu juga Soeharto resmi berhenti sebagai Presiden dan kemudian pada saat yang sama bertempat di Istana Merdeka tanggal 21 Mei 1998, Wakil Presiden B.J. Habibie diambil sumpahnya dihadapan Mahkamah Agung sebelum ia memangku jabatan Presiden pada waktu itu juga disaksikan oleh pimpinan DPR/MPR.

Seperti diketahui sebelum peristiwa itu berlangsung, bahkan jauh hari sebelum Sidang Umum MPR 1998, telah terjadi aksi demonstrasi yang dilakukan oleh para mahasiswa, baik di DKI Jakarta maupun di daerah-daerah lain. Walaupun belum begitu ramai, salah satu tuntutan dari aksi demonstrasi para mahasiswa tersebut yaitu agar MPR pada Sidang Umum tahun 1998 tidak mencalonkan kembali Soeharto sebagai Presiden Republik Indonesia periode 1998-2003. Namun tuntutan itu tidak ditanggapi oleh MPR, bahkan pada saat Sidang Umum berlangsung, MPR memilih kembali Soeharto sebagai Presiden Republik Indonesia periode 1998-2003. Tentu hal ini menambah gencarnya demonstrasi yang dilakukan oleh para mahasiswa, dengan tuntutan yakni agar Soeharto turun dari jabatannya. Demonstrasi ini semakin besar, dengan jatuhnya korban di pihak mahasiswa ketika dalam melakukan aksi demonstrasinya akibat

23 Abdul Gafur, Hari-hari Terakhir Seorang Presiden, Pustaka Sinar Harapan, Jakarta, 2000, hlm. 1-2 
terjadi bentrokan dengan aparat keamanan. Bahkan dengan adanya kejadian itu makin menimbulkan kerusuhan disejumlah tempat di Jakarta.

Pada tanggal 12 Mei 1998 empat mahasiswa Universitas Trisaksi tewas ditembak aparat keamanan saat berlangsung unjuk rasa proreformasi sebagai rangkaian unjuk rasa dari mahasiswa sebelumnya. Dua hari kemudian, kerusukan meluas ke seluruh wilayah (ibu kota). Anggota ABRI siap untuk berjaga namun keadaan semakin sulit untuk dikendalikan. Kemudian pada tanggal $16 \mathrm{Mei}$ 1998, Soeharto menerima Rektor dan Dosen dari Universitas Indonesia di kediamannya jalan Cendana No. 8, pada saat pertemuan itu Pak Harto menyatakan bahwa "menjadi Presiden bukan kemauan saya, melainkan wujud tanggung jawab sebagai Mandataris MPR, karena itu bila dikehendaki, saya siap lengser keprabon sejauh dilakukan secara konstitusional dan damai". Setelah itu Presiden Soeharto menerima pimpinan MPR/DPR. Ketua MPR/DPR Harmoko menyampaikan apsirasi masyarakat yang masuk ke DPR beserta beberapa dokumen. Intinya, menuntut reformasi disegala bidang termasuk me reshuffle kabinet, Sidang Istiemwa MPR dan meminta agar Pak Harto turun dari jabatan Presiden.

Pada tanggal 18 Mei, ratusan mahasiswa mendatangi Gedung MPR/DPR Senayan. Mereka menemui para anggota fraksi di DPR, mereka memutuskan tidak akan pulang sebelum Soeharto mundur.

Keesokan harinya, di Istana Negara, Pak Harto berkonsultasi dengan sembilan tokoh ulama dan cendekiawan: Abdurrahman Wahid (Ketua PB NU), Emha Ainun Nadjib (budayawan), Nurcholis Madjid (Direktur Yayasan Paramadina), Ali Yafie (Ketua MUI), Prof. Malik Fadjar dan Sumarsono (Muhammadiyah), Yusril Ihza Mahendra (guru besar HTN UI, KH. Cholid Badowi (Muslimin Indonesia), serta Ahmad Bagdja dan Ma'ruf Amin (NU). Dalam pertemuan selama dua setengah jam tersebut, para tokoh menyampaikan bahwa arti tuntutan reformasi tersebut sama dengan halnya meminta Pak Harto mundur. ${ }^{24}$

Dari hasil pertemuan itu, Pak Harto memutuskan untuk membentuk Komite Reformasi, me resbuffle Kabinet Pembangunan VII dan sekaligus mengganti namanya menjadi Kabinet Reformasi, serta melakukan Pemilu secepat-cepatnya berdasarkan UU Pemilu yang baru, ia juga menegaskan untuk tidak bersedia lagi dicalonkan sebagai Presiden. Presiden Soeharto juga membentuk Komite Reformasi, hal ini murni dari gagasan Presiden Soeharto. Melihat dari pertemuan itu, sesungguhnya tanda-tanda bahwa Soeharto akan mengundurkan diri sudah tampak. Namun keberadaan Kabinet Reformasi tersebut ditolak oleh mereka yang ditunjuk oleh Soeharto.

Pada saat bersamaan, di gedung MPR/DPR, pimpinan MPR/DPR mengadakan rapat dengan pimpinan fraksi DPR selama lima jam. Hasilnya masyarakat menghendaki agar Pak Harto mundur sebagai Presiden. Akhirnya

${ }^{24}$ Muhammad Najib dan Kuat Sukardiyono, Amin Rais..., Op Cit, hlm. 33 
pada tanggal 21 Mei 1998, Presiden Soeharto mengumumkan pengunduran dirinya sebagai Presiden Republik Indonesia, kemudian ditunjuk wakilnya yaitu Bacharuddin Jusuf Habibie. ${ }^{25}$

Ditinjau dari sudut pandang hukum tata negara, pengangkatan B.J. Habibie menjadi Presiden ketiga RI telah memenuhi kaidah Pasal 8 UUD 1945, yakni: "Ji8ka Presiden mangkat, berhenti atau tidak dapat melakukan kewajibannya dalam masa jabatannya, ia diganti oleh Wakil Presiden sampai batas waktunya habis".

Pengaturan lebih lanjut dari ketentuan Pasal 8 UUD 1945 adalah TAP MPR No. VII/MPR/1973 tentang keadaan Presiden dan/atau Wakil Presiden RI berhalangan. Pasal 2 TAP MPR No. VII/MPR/1973 menyebutkan:

1) Dalam hal Presiden berhalangan tetap, maka ia diganti oleh Wakil Presiden sampai habis masa jabatannya.

2) Wakil Presiden sebelum memegang masa jabatannya sebagaimana dimaksudkan ayat (1) pasal ini, bersumpah atau berjanji di hadapan DPR.

3) Apabila DPR untuk maksud tersebut pada ayat 92) pasal ini tidak mungkin mengadakan rapat maka Wakil Presiden bersumpah atau berjanji dihadapan Mahkamah Agung.

Prosedur penggantian Presiden tersebut menggunakan Pasal 2 ayat (1) TAP MPR No. VII/MPR/1973, sebab pada saat itu Gedung DPR/MPR RI diduduki oleh ribuan mahasiswa, sehingga Presiden B.J. Habibie disumpah di hadapan Mahkamah Agung.

Namun ada sebagian lagi yang berpendapat bahwa peralihan tersebut tidak sah (inkonstituisonal) karena menurut TAP MPR No. III/MPR/1978 tentang Kedudukan dan Hubungan Tata Kerja Lembaga Tertinggi dan Lembaga Tinggi Negara dengan/atau Antar Lembaga-lembaga Tinggi Negara lainnya. Di dalam Pasal 4 jo Pasal 6 mewajibkan kepada Presiden khusus diadakan untuk minta pertanggungjawaban Presiden dalam pelaksanaan Haluan Negara yang ditetapkan oleh Undang-Undang Dasar atau Majelis. Dan oleh karena Presiden Soeharto ketika itu tidak memberikan pertanggungjawaban kepada Majelis (MPR), maka naiknya B.J. Habibie sebagai Presiden menggantikan Soeharto dianggap tidak sah. ${ }^{26}$

Pasal 4 TAP MPR No.III/MPR/1978 memang mengatakan bahwa MPR "dapat" memberhentikan Presiden dengan berbagai alasan, antara lain "atas permintaan sendiri”. Presiden Soeharto meminta sendiri dengan alasan. Pertama, pada waktu itu ada tuntutan luas dalam masyarakat agar Soeharto "mundur sekarang juga". Andai waktu itu Soeharto minta berhenti kepada MPR, maka desakan agar "ia mundur sekarang juga" itu akan sulit dipenuhi. Dibutuhkan waktu yang cukup lama untuk melaksanakan Sidang Istimewa MPR.

${ }^{25}$ Ibid, hlm. 42

${ }^{26}$ Ni'matul Huda, “Bila Presiden Berhalangan Tetap”, Bernas, Jum'at, 3 Maret 2000 
Prosedurnya juga akan berbelit-belit. Kedua, MPR sendiri pada waktu itu dituding sebagai "sarang nepotisme". Kalau demikian siapa yang menjamin MPR akan mengabulkan permintaan Soeharto berhenti. Karena itu, tidak ada pilihan lain kecuali Soeharto membuat "pernyataan berhenti" secara sepihak. Dengan begitu, tidak diperlukan kata "setuju" atau "tidak setuju" dari MPR. Soeharto dengan serta merta berhenti dari jabatannya. Konsekuensinya dari tindakan ini adalah sesuai dengan bunyi Pasal 8 UUD 1945 dan Pasal 2 TAP MPR No.VII/MPR/ 1973, Wakil Presiden otomatis menggantikannya menjadi Presiden. ${ }^{27}$

Bahwa kemudian, ada pihak-pihak yang tidak suka B.J. Habibie menjadi Presiden, masalahnya bukan lagi menjadi masalah hukum namun menjadi masalah politik.

\section{Peralihan Kekuasaan Presiden B.J. Habibie ke Presiden Abdurrahman Wahid}

Pada proses peralihan kekuasaan Presiden KH. Abdurrahman Wahid sangat berbeda dengan masa-masa sebelumnya. Karena peralihan ini dianggap yang paling demokratis, dimulai dengan banyaknya partai dalam peserta Pemilu. Kemudian ditolaknya pidato pertanggungjawaban Presiden B.J. Habibie sampai terjadinya kompromi dari berbagai partai peserta Pemilu dalam MPR untuk mencalonkan KH. Abdurrahman Wahid sebagai Presiden. Dan yang paling menarik adalah terjadinya pemungutan suara (voting) dalam pengambilan keputusan pada pemilihan Presiden, sebab calon Presiden yang akan dipilih lebih dari satu orang, yaitu KH. Abdurrahman Wahid dan Megawati Soekarno Putri. Sistem pemilihan dan peralihan tersebut sesuai dengan Pasal 6 ayat (2) UUD 1945. Mekanismenya diatur dengan TAP MPR No. VI/MPR/1999 tentang Tata Cara Pencalonan dan Pemilihan Presiden dan Wakil Presiden Republik Indonesia.

Dalam pemilihan tersebut terdapat dua calon yang ditetapkan yaitu Abdurrahman Wahid dan Megawati Soekarno Putri, sehingga pemilihan dilakukan dengan pemungutan suara secara rahasia "one man one vote" (satu orang anggota MPR satu suara). Hasil pemungutan suara tersebut adalah Abdurrahman Wahid memperoleh 373 suara, sedangkan Megawati Soekarno Putri terpilih menjadi Wakil Presiden mendapat 313 suara, 9 abstain dan 4 dinyatakan tidak sah. $^{28}$

Maka Sidang MPR menetapkan KH. Abdurrahman Wahid sebagai Presiden Republik Indonesia untuk periode 1999-2004. Sedangkan Megawati Soekarno Putri terpilih menjadi Wakil Presiden setelah mengalahkan Hamzah

27 Yusril Ihza Mahendra, "Pertanggungjawaban Soeahrto", Republika, Selasa 8 September, 1998.

28 Arif Mudafsir Mandan, Memilih Gus Dur Menjadi Presiden, Georai Pratama Press dan Forum Indonesia Satu, Jakarta, 2000, hlm. 159 
Haz dengan 313 suara dan Hamzah Haz memperoleh 284 suara, serta 5 suara abstain. $^{29}$

\section{Peralihan Kekuasaan Presiden Abdurrahman Wahid ke Presiden Megawati Soekarno Putri}

Masa Republik keenam adalah periode diberlakukannya UUD 1945 setelah mengalami proses perubahan ketatanegaraan yang fundamental yang tetap dinamakan UUD 1945. Secara tepatnya periode ini dihitung mulai 10 Agustus 2002 sampai terjadinya perubahan yang fundamental terhadap konstitusi.

Dengan perubahan I-IV konstitusi selama masa republik V maka terjadi perubahan yang sangat fundamental dari segi ketatanegaraan. Dan dapat dikatakan lembaga-lembaga negara, termasuk lembaga kepresidenan mendapatkan kekuasaan, susunan dan kedudukan, tugas dan wewenang, serta hak dan kewajiban yang baru menurut "konstitusi yang baru".

Megawati Soekarnoputri adalah Presiden ke-5 Indonesia. Jabatan pertamanya dimulai 23 Juli 2001. Megawati menggantikan Abdurrahman Wahid karena posisinya sebagai Wakil Presiden. Ia adalah Wakil Presiden kedua yang menggantikan Presiden ketika berhenti dalam masa jabatannya. Megawati diangkat oleh MPR sebagai Presiden dengan Ketetapan MPR Nomor III/ MPR/2001 tentang Penetapan Wakil Presiden Republik Indonesia Megawati Soekarnoputri Sebagai Presiden Republik Indonesia. Masa jabatannya kurang dari 5 tahun sebab ia hanya mewarisi masa jabatan Abdurrahman Wahid. Presiden perempuan pertama Indonesia ini didampingi oleh Wakil Presiden Hamzah Haz yang memenangkan pemilihan wakil presiden oleh MPR dari rivalnya Susilo Bambang Yudhoyono. Hamzah oleh MPR diangkat sebagai wakil Presiden dengan Ketetapan MPR Nomor IV/MPR/ 2001 tentang Pengangkatan Wakil Presiden Republik Indonesia. Catatan dalam masa jabatannya adalah Pemilu Legislatif pada April 2004 serta Pemilo Presiden pada Juli 2004. Pada Pemilu Presiden 2004, Megawati harus mengakui keunggulan Susilo Bambang Yudoyono setelah melalui dua putaran pemilihan. Ia mengakhiri masa jabatan pertamanya pada 20 Oktober 2004 sehari lebih lama dari sisa masa jabatan Aburrahman Wahid yang dilimpahkan kepadanya.

\section{Peraihan Kekuasaan Presiden Megawati Soekarnoputri ke Presiden Susilo Bambang Yudoyono}

Susilo Bambang Yudhoyono adalah Presiden ke-6 Indonesia. untuk pertama kalinya Presiden ini langsung dipilih oleh rakyat Jabatan pertamanya dimulai pada 20 Oktober 2004. Ia bersama pasangannya Muhammad Jusuf Kalla memenangi Pemilu Presiden 2004 yang merupakan pemilihan presiden secara langsung yang pertama kali. Setelah mengakhiri masa jabatannya yang pertama, SBY kembali mengucapkan sumpah jabatan presiden untuk kedua

${ }^{29}$ Ibid, hlm. 166 
kalinya di hadapan sidang MPR pada 20 Oktober 2009 Kali ini ia didampingi oleh Boediono sebagai wakil presiden.

\section{Penutup}

Praktik pelaksanaan peralihan kekuasaan Presiden yang pernah terjadi di Indonesia, sebagian diawali dengan aksi kekerasan. Proses peralihan kekuasaan Presiden Soekarno ke Presiden Soeharto telah meninggalkan cerita yang sarat dengan muatan politik dan peristiwa Nawaksara sebagai suatu hal yang dianggap penting yang menandai tergulingnya Soekarno sebagai Presiden. Peralihan kekuasaan Presiden Soeharto ke Presiden B.J. Habibie yang diawali dengan demonstrasi dari mahasiswa yang menuntut Soeharto untuk mundur dari jabatannya sebagai Presiden. Yang berakhir dengan pengunduran diri dari Soeharto, yang kemudian jabatan sebagai Presiden diserahkan kepada Wakilnya B.J. Habibie, yang menimbulkan polemik tentang keabsahan Habibie sebagai Presiden. Dan terakhir peralihan kekuasaan dari Presiden Habibie ke Presiden Abdurrahman Wahid, yang dimulai dengan banyaknya partai politik peserta Pemilu yang akhirnya menimbulkan lebih dari satu orang calon Presiden, sehingga dilakukan pemilihan Presiden oleh MPR. Pada masa ini dianggap proses peralihan kekuasaan Presiden yang paling demokratis dalam sejarah ketatanegaraan Indonesia, yang mana pada Presiden sebelumnya dilaksanakan dengan pengangkatan karena selalu dengan calon tunggal.

Megawati menggantikan Abdurrahman Wahid karena posisinya sebagai Wakil Presiden. Ia adalah Wakil Presiden kedua yang menggantikan Presiden ketika berhenti dalam masa jabatannya.

Susilo Bambang Yudhoyono adalah Presiden ke-6 Indonesia. untuk pertama kalinya Presiden ini lansung dipilih oleh rakyat Jabatan pertamanya dimulai pada 20 Oktober 2004. Pada Pemilu berikutnya terpilih kembali untuk satu kali lagi masa jabatan.

\section{Daftar Pustaka}

Abdul Gafur, Hari-hari Terakhir Seorang Presiden, Pustaka Sinar Harapan, Jakarta, 2000.

A.K. Pringgodigdo, Kedudukan Presiden Menurut Tiga Undang-Undang Dasar dalam Teori dan Praktik, Pembangunan, Jakarta, 1956.

Ramlan Surbakti, Reformasi Kekuasaan Presiden, Grasindo, Jakarta, 1998.

Arif Mudafsir Mandan, Memilib Gus Dur Menjadi Presiden, Georai Pratama Press dan Forum Indonesia Satu, Jakarta, 2000.

Bagir Manan, Lembaga Kepresidenan, PSH UII dan Gama Media, Yogyakarta, 1999.

Dahlan Thaib, Pancasila Yuridis Ketatanegaraan, UPP-AMPYKPN, Yogyakarta, 1991.

Implementasi Sistem Ketatanegaraan Menurut UUD 1945, Liberty, Yogyakarta, 1993 
Dahlan Thaib dan Mila Karmila (editor), Hukum dan Kekuasaan, FH. UII dan Pustaka Pelajar Offset, Yogyakarta, 1998.

Harun Al-Rasyid, Himpunan Peraturan Hukum Tata Negara, UI Press, Jakarta, 1983.

Masalah Pengisian Jabatan Presiden Sejak Sidang Persiapan Kemerdekaan 1945 Sampai Sidang Majelis Permusyawaratan Rakyat 1993 (disertasi), Universitas Indonesia, Jakarta, 1993.

, Pengisian Jabatan Presiden, Pustaka Utama Grafiti, Jakarta, 1999.

, Jabatan Presiden Republik. Indonesia Sebuab Tinjauan Hukum Tata Negara Indonesia, dies rede, pada Sidang Senat Terbuka dalam Rangka Dies Natalis ke 56 UII, Yogyakarta, 8 Nopember 1999.

Jimly Asshiddiqie, Gagasan Kedaulatan Rakyat dalam Konstitusi dan Pelaksanaannya di Indonesia, Ichtiar Baru Van Hoeve, Jakarta, 1994.

Joeniorto, Sejarab Ketatanegaraan Republik Indonesia, Bina Aksara, Jakarta, 1990.

Mashudi, Mekanisme Kepemimpinan Nasional Lima Tabun, dalam Bagir Manan (editor), Kedaulatan Rakyat, Hak. Asasi Manusia dan Negara Hukum, (Gama Media Pratama, Jakarta, 1996.

Moh. Mahfud MD. Dasar dan Struktur Ketatanegaraan Indonesia, UII Press, Yogyakarta, 1993

Muhammad Najib dan Kuat Sukardiyono, Amin Rais Sang Demokrat, Gema Insani Press, Jakarta, 1998.

Mukhyar Yara, Pengisian Jabatan Presiden dan Wakil Presiden di Indonesia, Nadhila Ceria, Jakarta, 1995.

Ni'matul Huda, Hukum Tata Negara (Kajian Teoritis dan Yuridis terhadap Konstitusi Indonesia), PSH FH UH, Yogyakarta, 1999.

Padmo Wahjono, Beberapa Masalab ketatanegaraan di Indonesia, Rajawali, Jakarta, 1984.

Sekretariat Negara, Tiga Pulub Tabun Indonesia Merdeka, Tiara Pustaka, Jakarta, 1980.

Soehino, Hukum Tata Negara, Negara Kesatuan Republik Indonesia Berdasarkan Pancasila dan UUD 1945 adalah Negara Hukum, Liberty, Yogyakarta, 1985.

Sri Soemantri, Persepsi Terhadap Prosedur dan Sistem Perubahan Konstitusi dalam Batang Tubub UUD 1945, Alumni, Bandung, 1987.

Subhan SD, Suksesi, Pustaka Sinar Harapan, Jakarta, 1997.

Suwoto Mulyosudarmo, Peralihan Kekuasaan Kajian Teoritis dan Yuridis terhadap Pidato Nawaksara, Gramedia Pustaka Utama, Jakarta, 1997.

Yusril Ihza Mahendra, Dinamika Tata Negara Indonesia, Gema Insani Press, Jakarta, 1996. 
